\title{
MULTIPLE CRITERIA ASSESSMENT OF ALTERNATIVES FOR BUILT AND HUMAN ENVIRONMENT RENOVATION
}

\author{
Laura Tupenaite $^{1}$, Edmundas Kazimieras Zavadskas ${ }^{2}$, Arturas Kaklauskas ${ }^{3}$, \\ Zenonas Turskis ${ }^{4}$, Mark Seniut ${ }^{5}$ \\ 1, 2, 3, 4, 5 Vilnius Gediminas Technical University, Sauletekio al. 11, LT-10223 Vilnius, Lithuania, \\ ${ }^{1,2,4}$ Department of Construction Technology and Management \\ ${ }^{3}$ Department of Construction Economics and Property Management \\ ${ }^{5}$ Institute of Internet and Intelligent Technologies \\ E-mails: ${ }^{1}$ laura.tupenaite@vgtu.lt (corresponding author); ${ }^{2}$ edmundas.zavadskas@vgtu.lt; \\ 3arturas.kaklauskas@vgtu.lt; ${ }^{4}$ zenonas.turskis@vgtu.lt; ${ }^{5}$ mkos@delfi.lt \\ Received 7 Oct. 2009; accepted 22 Jan. 2010
}

\begin{abstract}
The built environment is not constructed in empty space. It refers to human - made spaces they live and work in and which are affected by various micro, meso and macro level factors. For this purpose, renovation decisions must be considered avoiding a narrow approach to the single projects of building renovation. Renovation of the built and human environment must be considered instead and the holistic approach used. From this perspective, decision-making problems of renovation often involve a complex decision making process in which multiple requirements and conditions have to be taken into consideration simultaneously. This paper describes the concept of the integrated analysis of built and human environment renovation as a whole as well as presents the multiple criteria assessment of alternatives of the Bulgarian cultural heritage renovation projects. The widely known multiple criteria assessment methods SAW, TOPSIS and COPRAS and the newly developed method ARAS were used for this purpose. As a result the best project for granting was selected.
\end{abstract}

Keywords: built and human environment renovation, model, hierarchically structured system of criteria, multiple criteria assessment, best alternative.

\section{Introduction}

The degree and rate of degradation of the built environment in Europe is of enormous economic and technical importance, since the value of the built environment represents approximately $50 \%$ of the national wealth of most countries (Long et al. 2001; Juan et al. 2009b).

Renovation is vitally important not only because of the immediate consequences - reduced energy consumption, improved state of buildings, etc. - but also because of positive external effects such as an increased quality of life, reduced climate change, etc.

It must be admitted that the built environment is not constructed in empty space. It refers to human - made spaces they live and work in and which are affected by various micro, meso and macro level factors. For this purpose, renovation decisions must be considered avoiding a narrow approach to the single projects of building renovation. Renovation of the built and human environment must be considered instead. Under this holistic approach, the complex renovation of living areas including various types of buildings (housing, commercial, public, etc.), infrastructure, the surrounding areas (parks, leisure zones, stadiums), etc. should be performed.

The object of this research integrates the renovation process of the built and human environment, participating stakeholders' groups with specific aims and external micro, meso and macro environments as a whole.

The paper presents the established Conceptual Model for the Integrated Analysis of Built and Human Environment Renovation (IABHER) as well as the multiple criteria assessment of the alternatives of renovation projects performed by the authors.

\section{The conceptual model for the integrated analysis of built and human environment renovation}

There is a considerable amount of scientific literature discussing renovation of buildings from different perspectives.

Much of empirical work on renovation is based on optimization models in which a homeowner or landlord chooses the level of capital investment to maximize some objective function. For instance, Juan et al. (2009a) proposed a decision-making model for housing refurbishment. The model conducts housing condition assessment and offers optimal refurbishment actions considering the trade-off between cost and quality. Zavadskas et al. (2004, 2008a) presented a mathematical model for the evaluation of investments into housing renovation. Martinaitis et al. (2007) applied a two-factor method for appraising building renovation and energy efficiency improvement projects. 
Other proposed models can be defined as the process-based models. For instance, Hassanien and Losekoot (2002) propose the basic model of hotel renovation process. This model consists of four fundamental interrelated phases, which are common to any type of renovation, including pre-planning, planning, implementation, and evaluation.

More complex models deal with Building Life Cycle Analysis and costs management (Shabha 2003; Banaitiene et al. 2008; Sobotka and Rolak 2009).

Recently, much attention has been paid to the issues of sustainable renovation reflecting in scientific models proposed by various researches (Caccavelli and Gurgerli 2002; Rey 2004; Mickaitytè et al. 2008 and others) as well as in the projects initiated and funded by the European Commission (i.e. SUREURO (Bueren et al. 2006), TOBUS (Caccavelli and Gurgerli 2002), Brita in Pubs (Bringing...2004).

The results of the conducted analysis demonstrate that renovation is discussed in various scientific models. Much attention is paid to renovation processes, decisionmaking, sustainable renovation principles, macro and sometimes micro environment factors. Indeed these models are oriented to particular processes or objects (housing, hotels, commercial buildings, etc.). There is no model presented in which built and human environment renovation is evaluated as a whole, considering all the elements of the built and human environment renovation process, stakeholders' needs and affecting macro, meso and micro level factors.
Following a category-based presentation of renovation strategies potentially applicable to all built and human environment, whole-system design is critical. The categories and strategies are interdependent and none stand in isolation. Decisions made in one area may affect performance in the other. Single improvement in design might make the performances of several building systems more advanced, i.e. careful decisions on building shape and window placement that take into account both prevailing wind and sun angles may not only enhance the thermal performance of a building but also result improve of day lighting. On the other hand, considering a single building alone with no regard to other structures may result a poorer performance of the built environment; for example, upgrading a building without solving infrastructure problems would only slightly increase the quality of living in the particular area and the maximal benefits of renovation will not be achieved. Any conflicts among categories should be resolved using an integrated design approach; careful decisions should be made to the types of design that can trigger multiple savings or other benefits. It is essential that all stakeholders work together and consider all sustainability categories in order to be aware of the influence of their decisions on the overall sustainability performance of the building in each category.

Based on these principles, the Conceptual Model for the Integrated Analysis of a Built and Human Environment Renovation (IABHER) was developed by the authors (Fig. 1).

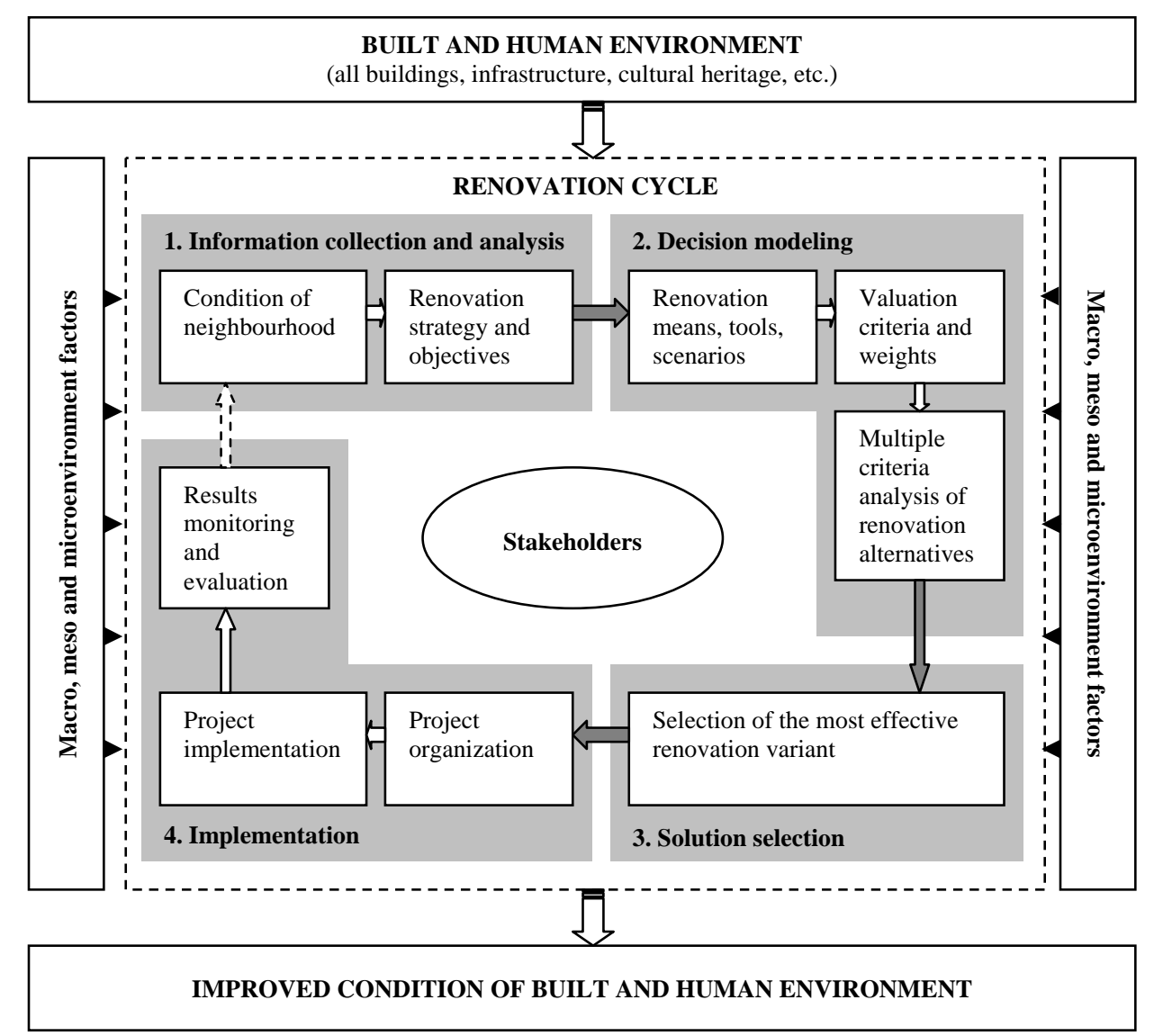

Fig. 1. Conceptual Model for the Integrated Analysis of a Built and Human Environment Renovation (IABHER) 
The main purpose of this model is to improve the condition of the built and human environment through efficient decision-making in renovation supported by multiple criteria evaluation methods, considering all macro, meso and micro environment factors as well as stakeholders' needs.

The model consists of the following elements:

- macro environment factors affecting built and human environment renovation;

- meso environment factors affecting built and human environment renovation;

- micro environment factors affecting built and human environment renovation;

- stakeholders participating in the renovation process;

- renovation cycle, consisting of four phases: information collection and analysis, decision modeling, solution selection and implementation.

The main elements are further discussed in more detail.

The highest level influencing the built and human environment as well as its renovation efficiency is macro level. In this level renovation of the built and human environment is influenced by social, political, economic, cultural, scientific, technical, etc. factors. In some circumstances each group of the mentioned factors can be crucial and renovation project can fail. In order to avoid negative impacts, it is important not to separate the consideration of renovation from macro environmental conditions and their changes. For instance, the slow down of economy had huge impact on investments into renovation in Lithuania - renovation projects stacked because of lack of funding. On the other hand, growing energy prices and heating costs will increase the interest of habitants in measures reducing energy consumption.

The changing role of the construction sector, with a focus on the service rendered by buildings, coupled with developing functions of construction firms in terms of diversification and vertical integration with particular emphasis on supply chain control, calls for a new approach of a mesoeconomic framework to assess the importance and scope of the construction sector beyond the narrow definition of construction activity (Ruddock 2009). From this perspective renovation analysis needs to go beyond just the construction firms to include the industry's professions and the materials industry as well as the service aspects, stock management organizations and the real estate sector.

The third level factors may be considered as the micro level and these depend upon those at the macro and meso level. The level of efficiency and the scope of activities of the renovation industry depend on the following micro variable factors: suitability of contractor to perform particular works, organization structure of contractor enterprise, sources of renovation financing, education and training of employees, know-how, types of contracts, etc.

In order to accurately assess the above mentioned macro, meso and micro efficiency level factors, it is necessary to develop a system of criteria fully describing each of them.
There are many stakeholders participating in decision-making process for built and human environment renovation: municipal technical personnel (usually named building administrators), municipal technical supervisors, buildings designers, contractors, buildings users, politicians, communities, society, etc. The aforementioned groups are making decisions for renovation; hereby their dissemination about the principles of the built and human environment renovation (as a whole) is very important. Furthermore, the major attempts must be made in order to satisfy usually conflicting stakeholders' needs.

In order to design and implement renovation of the built environment basing on sustainable development principles it is necessary to follow these principles from idea till implementation. Suitable decisions must be made starting from the brief stage (Šaparauskas and Turskis 2006; Šijanec Zavrl et al. 2009).

The process of renovation of the built and human environment can be divided into four main phases.

Data collection and analysis. At the initial phase renovation purposes, tasks, results, main participants, their aims and their relations are determined, type of building defined, analysis of renovation necessity performed.

Decision modeling phase. After aims and the need for renovation are defined, the next and very important phase is decision modeling. Information is analyzed, models formed, evaluation criteria selected and alternatives are distinguished in this phase.

Decision-making means the selection of the best alternative from numerous alternatives. Analysis of the built environment renovation and decision-making is sophisticated because of many possible alternatives appearing in aims establishment, projecting, construction, and usage stages. These alternatives sometimes not even interact. In order to create optimal renovation strategy all the stakeholders' needs must be considered. Accordingly, renovation alternatives must be analyzed basing on many criteria (Zavadskas et al. 2008a). In this phase also the information about already implemented renovation projects, best practice examples, strengths and weaknesses of the projects is needed.

Decision selection phase. The main aim of this phase is to select the best alternative, evaluate expected results and make the final decision. In order to choose the best decision (alternative) methods of multiple criteria analysis can be applied. It is very important to choose the most suitable method in this case and to select the alternative which satisfies the stakeholders' needs at the highest degree.

Multiple criteria decision making methods were used by many authors for various renovation tasks (Rey 2004; Alanne 2004; Dascalaki and Balaras 2004; Selih 2007; Perng et al. 2007; Juan et al. 2009a,b; Ginevičius et al. 2008; Kaklauskas et al. 2005, 2006; Zavadskas et al. 2008a, b, c).

Implementation phase. Implementation phase is the last phase of decision-making process. The decision is transferred to implementers and the examination if the best alternative was selected is made. The project per- 
formance should be evaluated during the development process as well as after finishing in order to assess the existing situation when compared with the planned.

The presented model allows coming to conclusion that multiple criteria decision making (MCDM) approach use to be the most advantageous for decision-making in the field of the built and human environment renovation. Some of the multiple criteria decision making methods are further discussed.

\section{Review of the multiple criteria decision making methods}

Although there are many comparative studies presented in literature, it must be stated that the selection of a method depends on the decision-making problem.

The availability of a wide selection of methods for solving MCDM problems, however, generates the paradox that the selection of an MCDM method for a given problem leads to an MCDM problem itself (Triantaphyllou 2000). This implies that the choice of a specific method in general influences the ranking outcome. The validity of ranking outcomes remains a problematic issue in MCDM as it was concerned by Bernroider and Stix (2007). Although the search for finding the best MCDM method may never end, research in this area of decisionmaking is still critical and valuable (Triantaphyllou 2000).

In this paper methods are examined with respect to their suitability for finding a solution to a matching problem for a renovation decisions. For this reason only those methods that are promising and the most popular are discussed in greater detail: SAW, TOPSIS, COPRAS and the newly developed method ARAS.

Simple additive weighting (SAW) method was summarized by MacCrimmon (1968). Its major principles were also described in the papers of Churchman and Ackoff (1954) and Klee (1971).

SAW is a widely-used method for aggregating several criteria. The method involves adding together criteria values for each alternative and applying weights to individual criteria. Criteria must be maintained using the same scale for this to be possible. Once values for all alternatives have been aggregated, the alternative with the highest (or lowest) value is then selected as the comparatively optimal solution.

$$
K^{*}=\left\{a_{j} \mid \max _{j} \sum_{i=1}^{m} q_{i} \bar{x}_{i j}\right\} ; i=\overline{1, m} ; j=\overline{1, n},
$$

here $a_{j}$ is the $j^{\text {th }}$ alternative; $m$ - number of attributes, $n$ - number of alternatives, $\bar{x}_{i j}$ - the normalized value of each $i^{\text {th }}$ attribute; $q_{i}$ - weights of significances of each attribute and $\sum_{i=1}^{m} q_{i}=1$.

Technique for order preference by similarity to an ideal solution (TOPSIS) (Hwang and Yoon 1981). The basic principle is that the chosen alternative should have the shortest distance from the ideal solution and the far- thest distance from the negative-ideal solution. A relative distance of the alternative $a_{j}$ from an ideal one is obtained as:

$$
K_{j}=\frac{L_{j}^{-}}{L_{j}^{+}+L_{j}^{-}} ; j=\overline{1, n} ; \text { where } K_{j}=[0,1],
$$

here $L_{j}^{+}$is a distance between the compared $j^{\text {th }}$ alternative and the ideal one; $L_{j}^{-}$- a distance between the compared $j^{\text {th }}$ alternative and the negatively ideal option.

COPRAS (A Method of Multiple Criteria Complex Proportional Evaluation) (Zavadskas and Kaklauskas 1996; Kaklauskas et al. 2006; Zavadskas et al. 2008c). This method assumes direct and proportional dependence of significance and priority of investigated alternatives on a system of attributes.

The significance (efficiency) of comparative alternatives is determined on the basis of describing positive ("pluses”) and negative (“minuses”) characteristics. Relative significance $Q_{j}$ of each alternative $a_{j}$ is found according to the formula:

$$
Q_{j}=S_{+j}+\frac{S_{-\min } \cdot \sum_{j=1}^{n} S_{-j}}{S_{-j} \cdot \sum_{j=1}^{n} \frac{S_{-\min }}{S_{-j}}}, j=\overline{1, n},
$$

here $S_{+j}$ is the sum of "pluses” of each $j^{\text {th }}$ alternative, $S_{-j}$ is the sum of "minuses” of each $j^{\text {th }}$ alternative, $S_{- \text {min }}$ is the minimum of $S_{-j}, n-$ number of alternatives.

In order to visually assess the efficiency of alternative the utility degree $N_{j}$ can be calculated. The degree of utility is determined by comparing the alternative analyzed with the most efficient alternative from the set of alternatives. In this case, all the utility degree values related to the alternative analyzed will be ranged from $0 \%$ to $100 \%$. The formula used for the calculation of alternative $a_{j}$ utility degree is given below:

$$
N_{j}=\frac{Q_{j}}{Q_{\max }} \cdot 100 \% .
$$

The method ARAS (Additive Ratio Assessment) (Zavadskas and Turskis 2010) assumes direct and proportional dependence of significance and priority of investigated alternatives on a system of attributes basing on additive ratio. The best alternative is considered as the alternative which is closest to the optimal solution, selected by the interested party.

The effectiveness index $R_{j}$ for each alternative is calculated as follows:

$$
R_{j}=\sum_{j=1}^{n} \bar{x}_{i j}=\sum_{i=1}^{m} \sum_{j=1}^{n} \hat{x}_{i j} ; i=\overline{1, m} ; j=\overline{1, n},
$$

here $\bar{x}_{i j}$ - the normalized value of each attribute; $\hat{x}_{i j}-$ the normalized weighted value of each attribute. 
The utility degree of each alternative is established in comparison to the optimal alternative and is calculated according to the formula:

$$
N_{j}^{*}=\frac{R_{j}}{R_{o p t}} \cdot 100 \% .
$$

The utility degree $N_{j}^{*}$ of alternative $a_{j}$ indicates satisfaction degree of demands and goals pursued by the interested parties - the greater is the $N_{j}^{*}$ the higher is the efficiency of the alternative. In this case, the significance $N_{\text {opt }}$ of the optimal alternative will always be the highest (equal to 100\%). The significances of all remaining alternatives are lower as compared with the optimal one.

\section{Case study}

History has left the countries of Central and Southern Europe with a rich and diverse heritage. With strained public finances, limited interest from private investors, and scarce EU funding for the cultural heritage sector, financing care and maintenance of cultural relics and monuments has often proved hard.

By making protection of cultural heritage one of the EEA (European Economic Area) and Norway Grants' core priority sectors, Iceland, Liechtenstein and Norway help to alleviate this lack of funding and contribute to securing cultural heritage for future generations.

Grants aimed at conservation and renovation of European cultural heritage have been made available to a broad range of applicants through close to 30 highly popular open calls across Central and Southern Europe. Recently the support is given to the new countries - Romania and Bulgaria.

The case study of Bulgarian projects assessment for granting purposes is analyzed in this chapter. The main task is to evaluate and select the most efficient and reasonable projects for granting. The authors of this paper have participated as experts in this assessment.

\subsection{Development of the criteria system for projects' assessment}

In order to evaluate the cultural heritage renovation projects, a system of criteria must be developed. Basing on the main concept of the previously established model, projects must be assessed with respect to whole possible effects on built and human environment - the holistic approach used. For this purpose macro, meso and micro environment criteria, stakeholders' needs and the elements of the renovation process itself should be considered.

The system of renovation projects' assessment criteria was developed by authors basing on the EEA Financial Mechanism and the Norwegian Financial Mechanism Appraisal Manual (2009) as well as on research results of the scientific literature.

The purpose of evaluation of the projects is to verify and assess their performance in the following areas:

- suitability of the applicant;

- relevance of the operation in a holistic context;
- choice and efficiency of methodology, approach and technical solution;

- risk control;

- economic and financial aspects and feasibility of the operation;

- cross-cutting issues (sustainable development, gender equity, good governance) ;

- bilateral relations;

- main quantitative indicators of the projects.

These eight assessment areas are described by specific assessment criteria to be evaluated in each renovation project case. As the projects are evaluated basing on 48 criteria and the evaluation problem is sophisticated, the hierarchical system of criteria was developed (Table 1).

\subsection{Determining weights of criteria}

There are many methods to derive subjective preference of decision makers regarding criteria weights in renovation projects evaluation. One of the most and widely applied method to derive criteria weights in multiple criteria analysis is Analytic Hierarchy Process (AHP) (Saaty 1980).

AHP is becoming quite popular in research due to the fact that its utility outweighs other research methods (Cheng and Li 2001). This method is proposed to use in determining weights of the criteria in this research. The algorithm is presented in Fig. 2.

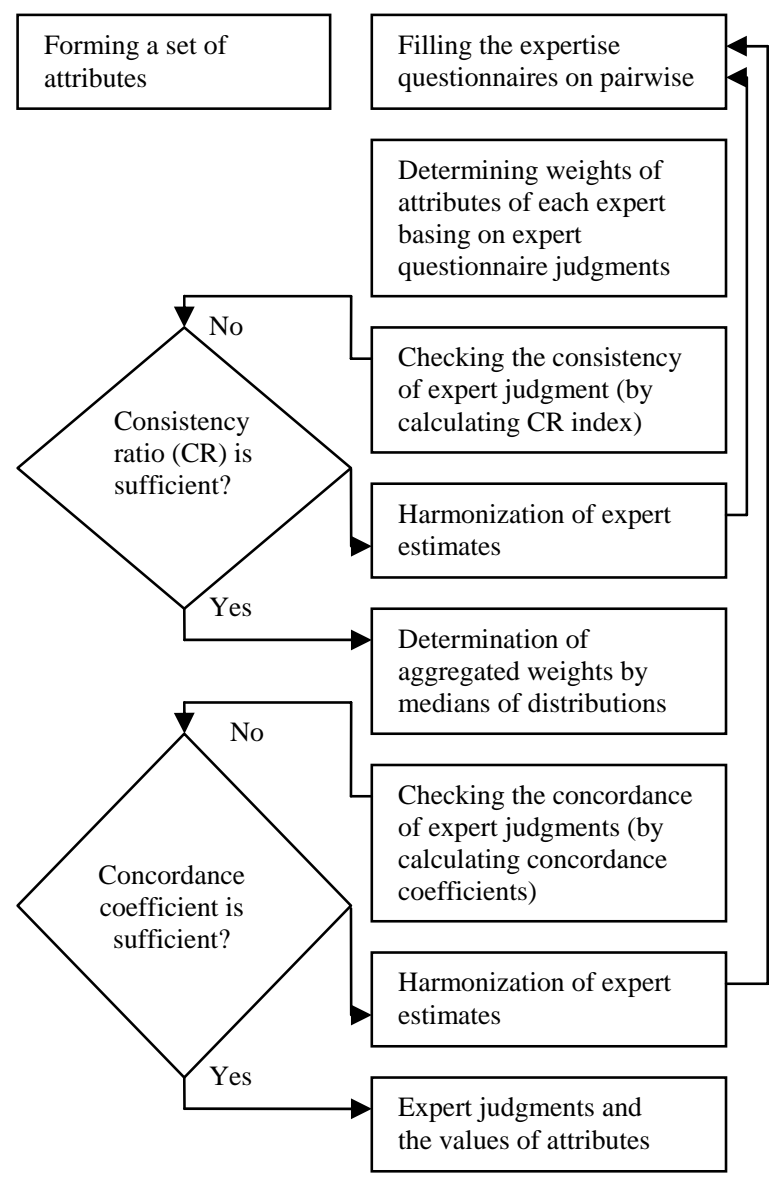

Fig. 2. Proposed algorithm for determination of weights of criteria by pairwise comparison 
Very important issue in this research was to select the experts having appropriate experience in fields of projects assessment for granting purposes (i.e. EU structural funds, EEA grants) as well as experience in renovation projects. Seven experts fully satisfied the requirements and were selected for this survey.

The questionnaires, consisting of judgment matrices were prepared and provided to experts. Judgment matrices filled by experts were used for the calculations of criteria weights and the consistency ratio $(C R)$ of each matrix was checked. Further calculated weights of each expert were aggregated and assumed as distribution and the medians of these distributions were calculated in order to determine the final weights of criteria.

The determined criteria weights as well as weights of criteria groups are presented in Table 1.

\subsection{Description of the evaluated projects}

In this case study five Bulgarian cultural heritage renovation projects were analyzed and assessed:

Alternative 1. Restoration and conservation of " $\mathrm{Ma}$ gura" historical complex. The project is connected to the realization measures for protection on the cultural historical heritage of the historical complex "Magura" and for the more attractive presentation and promotion on this wealth (Fig. 3).

Alternative 2. Revival and preservation of traditional building techniques and skills used in Bulgaria. The project aims at revival and preservation of the traditional knowledge and skills in old building techniques applied in Bulgaria (Fig. 4).

Alternative 3. Reconstruction of the Onbashieva House as part of the Vassil Levski National Museum in Karlovo and popularization of the life and deed of the Bulgarian national hero Vassil Levski as part of the

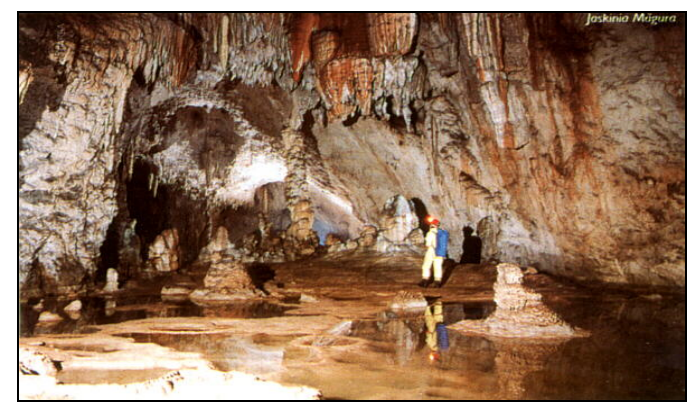

Fig. 3. Fragments of historical complex "Magura”

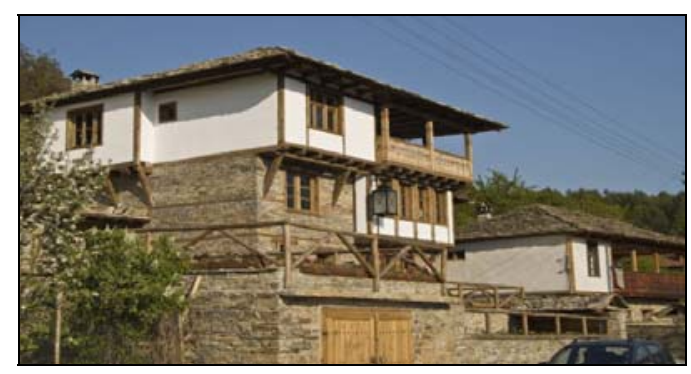

Fig. 4. Traditional Bulgarian building
European cultural heritage (Fig. 5). The overall objective of the project is to popularize the life and deed of the Bulgarian national hero Vassil Levski as part of the European cultural heritage. The specific purpose of the project is to reconstruct the Onbashieva house as part of Vassil Levski National Museum in Karlovo, by fully completing the Memorial Complex.

Alternative 4. Opening of "Sofia Arsenal" museum for contemporary art. The project is pursuing the common goal of conservation of the European cultural heritage by creating conditions for cultural socialization, educational and research work in the field of contemporary art.

The achievement of the common goal presupposes the accomplishment of the specific one - opening of a Contemporary Art Museum situated in a historical building from the end of the 19th century following an architectural reconstruction of the building and the surrounding area (Fig. 6).

Alternative 5. Restoration and conservation of Shumen Fortress - cradle of the civilizations that lived in Bulgaria. The aim of the project proposal is conservation and restoration of Historical-Archaeological Reserve "Shumen Fortress" and transformation of the object into an attractive destination for Bulgarian and foreign visitors (Fig. 7).

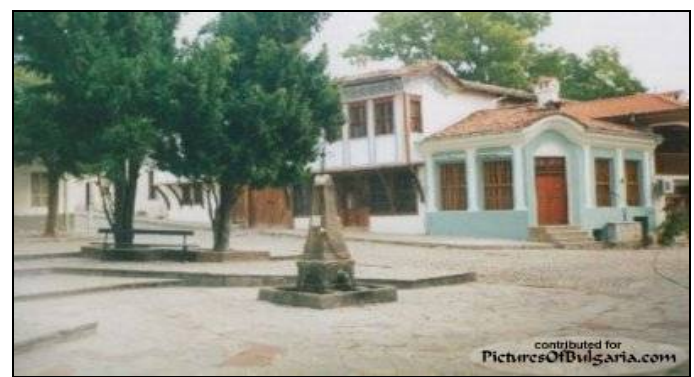

Fig. 5. Onbashieva House in Karlovo

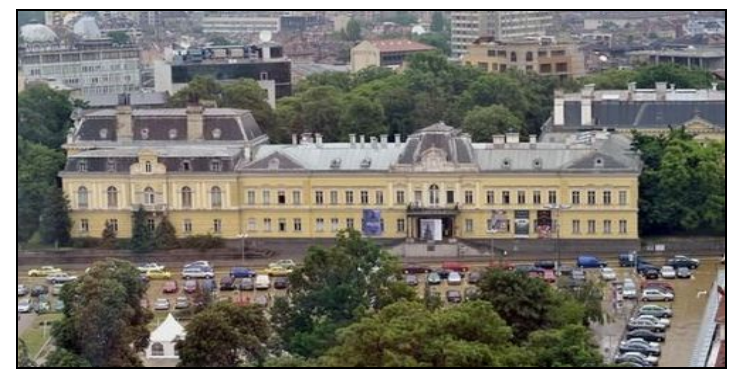

Fig. 6. Historical monumental building the South Park of Sofia

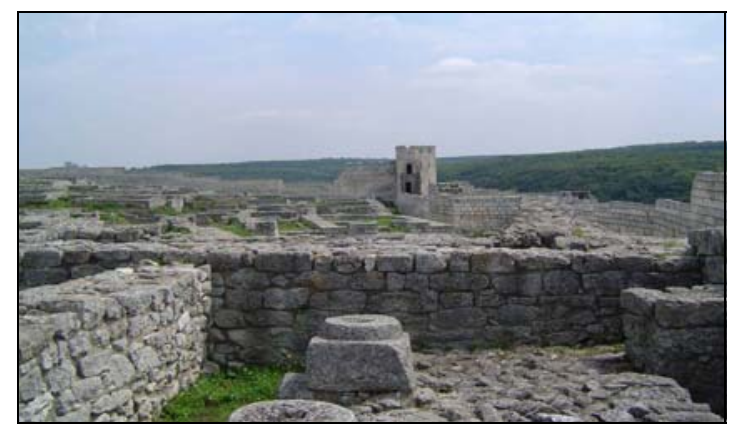

Fig. 7. "Shumen Fortress" in Bulgaria 
Table 1. Description of the analyzed projects` alternatives (assessment criteria, weights and attributes of alternatives)

\begin{tabular}{|c|c|c|c|c|c|c|c|c|}
\hline \multirow{2}{*}{ Criteria } & \multirow{2}{*}{$\begin{array}{l}\text { Weight } \\
\quad\left(q_{i}\right)\end{array}$} & \multirow{2}{*}{$\begin{array}{l}\text { Min/ } \\
\text { Max }\end{array}$} & \multicolumn{6}{|c|}{ Alternatives } \\
\hline & & & $A_{1}$ & $A_{2}$ & $A_{3}$ & $A_{4}$ & $A_{5}$ & $A_{\mathrm{opt}}$ \\
\hline 1 & 2 & 3 & 4 & 5 & 6 & 7 & 8 & 9 \\
\hline Applicant suitability $\left(C_{1}\right)$ & 0.0592 & Max & & & & & & \\
\hline Suitability of the applicant to implement the project $\left(c_{1}\right)$ & 0.2560 & Max & 4 & 4 & 4 & 4 & 5 & 5 \\
\hline Suitability of the project partners $\left(c_{2}\right)$ & 0.2510 & $\operatorname{Max}$ & 1 & 4 & 4 & 1 & 4 & 5 \\
\hline Suitability of the organisational resources / structure $\left(c_{3}\right)$ & 0.2968 & $\operatorname{Max}$ & 4 & 4 & 4 & 4 & 4 & 5 \\
\hline Adequateness of the publicity plan for the operation $\left(c_{4}\right)$ & 0.1962 & $\operatorname{Max}$ & 3 & 3 & 3 & 1 & 3 & 5 \\
\hline Relevance of the project $\left(C_{2}\right)$ & 0.1567 & Max & & & & & & \\
\hline Justification of the project $\left(c_{5}\right)$ & 0.1531 & Max & 4 & 3 & 4 & 4 & 3 & 5 \\
\hline Public consensus about the project $\left(c_{6}\right)$ & 0.0678 & Max & 4 & 4 & 4 & 4 & 4 & 5 \\
\hline Relevance of the overall project objective $\left(c_{7}\right)$ & 0.1473 & Max & 4 & 4 & 4 & 4 & 5 & 5 \\
\hline $\begin{array}{l}\text { Meeting of the purpose of the project to the needs expressed by the } \\
\text { applicant }\left(c_{8}\right)\end{array}$ & 0.0502 & Max & 4 & 4 & 4 & 4 & 3 & 5 \\
\hline Purpose contribution in a national or regional perspective $\left(c_{9}\right)$ & 0.2368 & Max & 4 & 5 & 4 & 4 & 4 & 5 \\
\hline Innovativeness of the project $\left(c_{10}\right)$ & 0.1731 & $\operatorname{Max}$ & 4 & 4 & 3 & 3 & 5 & 5 \\
\hline Implementation of EU legislation (c11) & 0.1717 & Max & 4 & 3 & 3 & 3 & 3 & 5 \\
\hline Methodological efficiency $\left(C_{3}\right)$ & 0.1672 & $\operatorname{Max}$ & & & & & & \\
\hline $\begin{array}{l}\text { Effectiveness of the proposed solution compared to alternative solu- } \\
\text { tions to the same problem }\left(c_{12}\right)\end{array}$ & 0.1599 & Max & 3 & 3 & 1 & 3 & 3 & 5 \\
\hline The choice of technology in a best available technique context $\left(c_{13}\right)$ & 0.1420 & Max & 3 & 3 & 3 & 3 & 3 & 5 \\
\hline Clarity and feasibility of the time schedule $\left(c_{14}\right)$ & 0.1631 & Max & 3 & 3 & 3 & 3 & 4 & 5 \\
\hline Relevance of the division into separate project activities $\left(c_{15}\right)$ & 0.0496 & $\operatorname{Max}$ & 3 & 3 & 3 & 4 & 3 & 5 \\
\hline Suitability of the proposed indicators $\left(c_{16}\right)$ & 0.1289 & Max & 3 & 4 & 3 & 4 & 4 & 5 \\
\hline Capacity building and human resources development $\left(c_{17}\right)$ & 0.1445 & Max & 1 & 4 & 1 & 1 & 1 & 5 \\
\hline Operation and maintenance $\left(c_{18}\right)$ & 0.2121 & Max & 3 & 4 & 4 & 4 & 3 & 5 \\
\hline Risk control $\left(C_{4}\right)$ & 0.1473 & Max & & & & & & \\
\hline Control of the managerial risks $\left(c_{19}\right)$ & 0.1078 & Max & 3 & 3 & 4 & 3 & 4 & 5 \\
\hline Control of the technical risks $\left(c_{20}\right)$ & 0.2501 & $\operatorname{Max}$ & 3 & 3 & 4 & 3 & 4 & 5 \\
\hline Control of the financial risks $\left(c_{21}\right)$ & 0.2501 & $\operatorname{Max}$ & 3 & 3 & 4 & 3 & 4 & 5 \\
\hline Control of the legal risks $\left(c_{22}\right)$ & 0.1375 & $\operatorname{Max}$ & 3 & 3 & 4 & 3 & 4 & 5 \\
\hline Suitability of the management and control of risk $\left(c_{23}\right)$ & 0.2545 & $\operatorname{Max}$ & 3 & 3 & 4 & 3 & 4 & 5 \\
\hline Economic feasibility $\left(C_{5}\right)$ & 0.1581 & $\operatorname{Max}$ & & & & & & \\
\hline Feasibility of the budget $\left(c_{24}\right)$ & 0.1904 & Max & 3 & 4 & 4 & 3 & 3 & 5 \\
\hline Revenue generation and additional benefit $\left(c_{25}\right)$ & 0.0846 & Max & 3 & 3 & 1 & 1 & 3 & 5 \\
\hline Co-financing feasibility $\left(c_{26}\right)$ & 0.1019 & Max & 3 & 4 & 4 & 4 & 3 & 5 \\
\hline Applicant's control of any in-kind contributions $\left(c_{27}\right)$ & 0.0590 & Max & 3 & 3 & 4 & 3 & 3 & 5 \\
\hline Cost-effectiveness of the project $\left(c_{28}\right)$ & 0.2739 & $\operatorname{Max}$ & 3 & 4 & 4 & 3 & 3 & 5 \\
\hline Economic life and post completion financing $\left(c_{29}\right)$ & 0.2903 & Max & 3 & 3 & 4 & 4 & 4 & 5 \\
\hline Contribution to cross-cutting targets $\left(C_{6}\right)$ & 0.0420 & Max & & & & & & \\
\hline Recovery of natural resources $\left(c_{30}\right)$ & 0.1233 & Max & 3 & 4 & 3 & 5 & 4 & 5 \\
\hline Strengthening of financial tools for ecosystem protection $\left(c_{31}\right)$ & 0.0685 & $\operatorname{Max}$ & 3 & 3 & 3 & 3 & 3 & 5 \\
\hline $\begin{array}{l}\text { Increase of public understanding of sustainability and positive influ- } \\
\text { ence on citizens' sustainability behaviour }\left(c_{32}\right)\end{array}$ & 0.1071 & Max & 4 & 4 & 4 & 4 & 4 & 5 \\
\hline Positive effects for public health $\left(c_{33}\right)$ & 0.0722 & Max & 4 & 4 & 3 & 3 & 4 & 5 \\
\hline Contribution to poverty reduction $\left(c_{34}\right)$ & 0.1040 & Max & 4 & 3 & 3 & 3 & 4 & 5 \\
\hline Promotion of women's participation within the project $\left(c_{35}\right)$ & 0.0723 & Max & 3 & 3 & 3 & 3 & 3 & 5 \\
\hline $\begin{array}{l}\text { Improvement of participation of civil society into decision making } \\
\text { processes }\left(c_{36}\right)\end{array}$ & 0.3005 & $\operatorname{Max}$ & 3 & 3 & 3 & 3 & 3 & 5 \\
\hline Proactive approach to preventing and dealing with corruption $\left(c_{37}\right)$ & 0.1521 & Max & 3 & 3 & 3 & 3 & 3 & 5 \\
\hline Bilateral Relations $\left(C_{7}\right)$ & 0.0700 & Max & & & & & & \\
\hline Partnership contribution to the quality or success of the project $\left(c_{38}\right)$ & 0.2540 & $\operatorname{Max}$ & 1 & 4 & 4 & 1 & 4 & 5 \\
\hline $\begin{array}{l}\text { Indications development and good working relations between the } \\
\text { partners }\left(c_{39}\right)\end{array}$ & 0.2540 & Max & 1 & 3 & 4 & 1 & 4 & 5 \\
\hline Potential to develop the partnership beyond the project cooperation $\left(c_{40}\right)$ & 0.2939 & Max & 1 & 4 & 4 & 1 & 4 & 5 \\
\hline $\begin{array}{l}\text { Identification of the forms of bilateral relations other than partnerships } \\
\left(c_{41}\right)\end{array}$ & 0.1981 & Max & 1 & 1 & 4 & 1 & 3 & 5 \\
\hline Main quantitative indicators of the project $\left(C_{8}\right)$ & 0.1892 & Max & & & & & & \\
\hline Project budget (Thousands Euro) $\left(c_{42}\right)$ & 0.1520 & Min & 339 & 399 & 305 & 2252 & 353 & 305 \\
\hline Duration of the project (months) $\left(c_{43}\right)$ & 0.1245 & Min & 24 & 24 & 24 & 22 & 24 & 22 \\
\hline Staff involved in the project management (number) $\left(c_{44}\right)$ & 0.0435 & Max & 5 & 5 & 6 & 8 & 5 & 10 \\
\hline Reconstruction average expenses (Thousands Euro per sq. m.) $\left(c_{45}\right)$ & 0.1801 & Min & 0.87 & 0.37 & 0.65 & 1.80 & 0.14 & 0.14 \\
\hline Area of the newly developed infrastructure (thousands of sq.m) $\left(c_{46}\right)$ & 0.2155 & Max & 3 & 0.391 & 0.25 & 1 & 2.5 & 3 \\
\hline Visitors increase after project implementation (thousands of people) $\left(c_{47}\right)$ & 0.1335 & Max & 30 & 10 & 35.2 & 30 & 15.76 & 40 \\
\hline Number of conserved and/or protected items $\left(c_{48}\right)$ & 0.1509 & Max & 3 & 5 & 5 & 8 & 5 & 10 \\
\hline
\end{tabular}


All the alternatives of the projects are further assessed by the experts. For the criteria groups $C_{1}-C_{7}$ the assessment of attributes is qualitative. For each group of attribute value a score is given according to the assessment from ,very poor“ (score 1), "poor” (2), “adequate” (3), "good” (4) and "very good” (5). For criteria group $C_{8}$ quantitative assessment is given basing on information provided in application forms. Thus the decision matrix for multiple criteria evaluation of the projects is prepared as well as the attribute values of the optimal alternative (for assessment by ARAS method) established (Table 1).

\subsection{Multiple Criteria Assessment of the Projects}

Multiple criteria assessment of the projects' alternatives is performed basing on the previously described methods SAW, TOPSIS, COPRAS and ARAS in respect to hierarchically structured system of evaluation criteria. For this purpose the calculations must be performed in two cycles - at first in lower hierarchy levels of criteria and after - in the highest level of criteria. This hierarchical evaluation is advantageous to experts or other decision makers - they can evaluate performance of each project in certain group of criteria as well as according to all groups of criteria.

The results obtained in applying all of the four methods are presented in Table 2 and the ranks of the alternatives' priorities - in Table 3.

Table 2. Data obtained by calculating the efficiency of the alternatives by various methods

\begin{tabular}{l|c|c|c|c|c|c}
\hline \multirow{2}{*}{ Method } & \multirow{2}{*}{$\begin{array}{c}\text { Ranking } \\
\text { index }\end{array}$} & \multicolumn{5}{|c}{ Alternatives } \\
\cline { 3 - 7 } & & $A_{1}$ & $A_{2}$ & $A_{3}$ & $A_{4}$ & $A_{5}$ \\
\hline SAW & $K^{*}$ & 0.81 & 0.86 & 0.89 & 0.78 & 0.95 \\
\hline TOPSIS & $K_{j}$ & 0.34 & 0.53 & 0.52 & 0.19 & 0.66 \\
\hline COPRAS & $N_{j}$ & 86.5 & 93.7 & 94.3 & 84.9 & 100 \\
\hline ARAS & $N_{j}^{*}$ & 58.4 & 63.2 & 64.4 & 54.9 & 71.5 \\
\hline
\end{tabular}

Table 3. Ranks of the alternatives' priorities by various methods

\begin{tabular}{l|c|c|c|c|c}
\hline \multirow{2}{*}{ Method } & \multicolumn{5}{|c}{ Alternatives } \\
\cline { 2 - 6 } & $A_{1}$ & $A_{2}$ & $A_{3}$ & $A_{4}$ & $A_{5}$ \\
\hline SAW & 4 & 3 & 2 & 5 & 1 \\
\hline TOPSIS & 4 & 2 & 3 & 5 & 1 \\
\hline COPRAS & 4 & 3 & 2 & 5 & 1 \\
\hline ARAS & 4 & 3 & 2 & 5 & 1 \\
\hline
\end{tabular}

SAW, COPRAS and ARAS methods provided equal results (ranks of alternatives' priorities), indeed the rank of alternatives' priorities determined by TOPSIS method differs considering the performance of alternatives $A_{2}$ and $A_{3}$. The alternative $A_{3}$ according to SAW, COPRAS and ARAS methods is the second best, indeed according to TOPSIS method it is in the third place, although its distance only to a small extent differs from the $A_{2}$ alternative's. As three methods out of four have given the same results, in further research of the projects of built and human renovation it is recommended to carefully assess the results obtained by TOPSIS method.

On the basis of the analysis of the results, funding should be firstly granted to the project alternative $A_{5}$ (Restoration and conservation of Shumen Fortress) and secondarily to the following projects in the priorities list, according to the available funds. The least project alternative is $A_{4}$ (Opening of "Sofia Arsenal" museum for contemporary art).

\section{Conclusions}

The Conceptual Model for the Integrated Analysis of Built and Human Environment Renovation (IABHER) was developed. The main purpose of this model is to improve condition of the built and human environment through efficient decision-making in renovation supported by multiple-criteria evaluation methods, considering all the macro, meso and micro environment factors as well as stakeholders needs.

The model was applied in the case study of five Cultural Heritage Renovation Projects in Bulgaria for EEA and Norway Grants.

In order to evaluate the cultural heritage renovation projects, a hierarchical system of criteria, consisting of 8 criteria groups and 48 sub-criteria, was developed. Based on this system projects are evaluated with respect to whole possible effects on built and human environment the holistic approach is used, macro, meso and micro environment factors considered.

Weights of criteria were estimated by experts and calculated by AHP method.

The multiple criteria analysis of the projects by SAW, COPRAS and ARAS methods revealed the same results. The best alternative established is Restoration and conservation of Shumen Fortress and the least alternative is Opening of "Sofia Arsenal" museum for contemporary art.

\section{References}

Alanne, K. 2004. Selection of renovation actions using multicriteria "knapsack" model, Automation in Construction 13(3): 377-391. doi:10.1016/j.autcon.2003.12.004

Banaitiene, N.; Banaitis, A.; Kaklauskas, A.; Zavadskas, E. K. 2008. Evaluating the life cycle of building: a multivariant and multiple criteria approach, Omega - International Journal of Management Science 36: 429-441. doi:10.1016/j.omega.2005.10.010

Bernroider, E. and Stix, V. 2007. A method using weight restrictions in data envelopment analysis for ranking and validity issues in decision making, Computers \& Operations Research 34: 2637-2647. doi:10.1016/j.cor.2005.10.005

Bringing Retrofit Innovation to Application in Public Buildings (BRITA in PuBs). 2004. EU 6th Framework Program, Integrated Project BRITA in PuBs. Available from Internet: $<$ http://www.brita-in-pubs.com/summary.html>.

Bueren, Van, E.; Voort, Van der, H.; Maas, N. 2006. The Sureuro Gaming Exercise: designing a game for sustainable refurbishment by housing companies, Journal of Design Research 5(2): 201-223. 
Caccavelli, D. and Gurgerli, H. 2002. TOBUS - a European diagnosis and decision - making tool for office building upgrading, Energy and Buildings 34: 113-119. doi:10.1016/S0378-7788(01)00100-1

Cheng, E. W. and Li, H. 2001. An approach to determine measures for business performance, Measuring Business Excellence 5(3): 30-37. doi:10.1108/EUM0000000005864

Churchman, C. W. and Ackoff, R. L. 1954. An approximate measure of value, Journal of Operations Research Society of America 78: 367-379.

Dascalaki, E. and Balaras, C. A. 2004. XENIOS - a methodology for assessing refurbishment scenarios and the potential of application of RES and RUE in hotels, Energy and Buildings 36:1091-1105. doi:10.1016/j.enbuild.2004.03.007

EEA Financial Mechanism and the Norwegian Financial Mechanism Appraisal Manual. 2009. Version 3. Norway.

Ginevičius, R.; Podvezko, V.; Raslanas, S. 2008. Evaluating the alternative solutions of wall insulation by multicriteria methods, Journal of Civil Engineering and Management 14(4): 217-226. doi:10.3846/1392-3730.2008.14.20

Hassanien, A. and Losekoot, E. 2002. The application of facilities management expertise to the hotel renovation process, Facilities 20(7/8): 230-238. doi:10.1108/02632770210435143

Hwang, C.-L. and Yoon, K.-P. 1981. Multiple attribute decision making: methods and applications. NewYork: Springer.

Juan, Y.-K.; Kim, J. H.; Roper, K.; Castro-Lacouture, D. 2009a. GA-based decision support system for housing condition assessment and refurbishment strategies, Automation in Construction 18(4): 394-401. doi:10.1016/j.autcon.2008.10.006

Juan, Y.-K.; Perng, Y.-H.; Castro-Lacouture, D.; Lu, K.-Sh. 2009b. Housing refurbishment contractors' selection based on a hybrid fuzzy-QFD approach, Automation in Construction 18(2): 139-144. doi:10.1016/j.autcon.2008.06.001

Kaklauskas, A.; Zavadskas, E. K.; Raslanas, S. 2005. Multivariant design and multiple criteria analysis of building refurbishments, Energy and Buildings 37: 361-372. doi:10.1016/j.enbuild.2004.07.005

Kaklauskas, A.; Zavadskas, E. K.; Raslanas, S.; Ginevičius, R.; Komka, A.; Malinauskas, P. 2006. Selection of low - e windows in retrofit of public buildings by applying multiple criteria method COPRAS: A Lithuanian case, Energy and Buildings 38(5): 454-462. doi:10.1016/j.enbuild.2005.08.005

Klee, A. J. 1971. The role of decision models in the evaluation of competing environmental health alternatives, Management Science 18(2): 52-67. doi:10.1287/mnsc.18.2.B52

Long, A. E.; Henderson, G. D.; Montgomery, F. R. 2001. Why assess the properties of near-surface concrete?, Construction and Building Materials 15: 65-79. doi:10.1016/S0950-0618(00)00056-8

MacCrimmon, K. R. 1968. Decision making among multiple attribute alternatives: A Survey and Consolidated Approach, RAND Memorandum, RM-4823-ARPA.

Martinaitis, V.; Kazakevičius, E.; Vitkauskas, A. 2007. A twofactor method for appraising building renovation and energy efficiency improvement projects, Energy Policy 35(1): 192-201. doi:10.1016/j.enpol.2005.11.003

Mickaitytė, A.; Zavadskas, E. K.; Kaklauskas, A.; Tupėnaitė, L. 2008. The concept model of sustainable buildings refur- bishment, International Journal of Strategic Property Management 12(1): 53-68.

doi:10.3846/1648-715X.2008.12.53-68

Perng, Y.-H.; Hsia, Y.-P.; Lu, H. J. 2007. Service quality improvement dynamic decision support system for refurbishment contractors, Total Quality Management \& Business Excellence 18(7): 731-749. doi:10.1080/14783360701349716

Rey, E. 2004. Office building retrofitting strategies: multicriteria approach of an architectural and technical issue, Energy and Buildings 36(4): 367-372. doi:10.1016/j.enbuild.2004.01.015

Ruddock, L. 2009. The scope of the construction sector: determining its value, in Les Ruddock (Ed.). Economics for the Modern Built Environment. Taylor \& Francis, 79-94.

Saaty, T.L. 1980. The analytic Hierarchy Process: Planning, Priority setting, Resource Allocation. McGraw-Hill International Book Company.

Selih, J. 2007. Residential building stock refurbishment design supported by a multi criteria decision support system, WSEAS Transactions on Systems 6(6): 1124-1131.

Shabha, Gh. 2003. A low-cost maintenance approach to highrise flats, Facilities 21(13/14): 315-322. doi:10.1108/02632770310507971

Sobotka, A. and Rolak, Z. 2009. Multi-attribute analysis for the eco-energetic assessment of the building life cycle, Technological and Economic Development of Economy 15(4): 593-611. doi:10.3846/1392-8619.2009.15.593-611

Šaparauskas, J. and Turskis, Z. 2006. Evaluation of construction sustainability by multiple criteria methods, Technological and Economic Development of Economy 12(4): 321-326.

Šijanec Zavrl, M.; Žarnić, R.; Šelih, J. 2009. Multicriterial sustainability assessment of residential buildings, Technological and Economic Development of Economy 15(4): 612-630. doi:10.3846/1392-8619.2009.15.612-630

Triantaphyllou, E. 2000. Multi-Criteria Decision Making Methods: a Comparative Study. Boston: Kluwer Academic Publishers.

Zavadskas, E. K. and Kaklauskas, A. 1996. Pastatu sistemotechninis juvertinimas [Multiple criteria evaluation of buildings]. Vilnius: Technika.

Zavadskas, E. K.; Kaklauskas, A.; Raslanas, S. 2004. Evaluation of investments into housing renovation, International Journal of Strategic Property Management 8(3): 177190.

Zavadskas, E. K; Raslanas, S.; Kaklauskas, A. 2008a. The selection of effective retrofit scenarios for panel houses in urban neighborhoods based on expected energy savings and increase in market value: The Vilnius case, Energy and Buildings 40(4): 573-587.

Zavadskas, E. K; Kaklauskas, A.; Galinienė, B. 2008b. A building's refurbishment knowledge-based decision support system, International Journal of Environment and Pollution 35(2/3/4): 237-249.

Zavadskas, E. K.; Kaklauskas, A.; Turskis, Z.; Tamosaitiene, J. 2008c. Selection of the effective dwelling house walls applying attributes determined in intervals, Journal of Civil Engineering and Management 14(2): 85-93. doi:10.3846/1392-3730.2008.14.3

Zavadskas, E. K. and Turskis, Z. 2010. A new additive ratio assessment (ARAS) method in multi-criteria decision making, Technological and Economic Development of Economy 16(2): 159-172. doi:10.3846/tede.2010.10 


\section{DAUGIAKRITERINIS GYVENAMOSIOS APLINKOS ATNAUJINIMO PROJEKTU VERTINIMAS}

\section{Tupėnaitė, E. K. Zavadskas, A. Kaklauskas, Z. Turskis, M. Seniut}

S a n tra u a

Gyvenamoji aplinka sukurta žmonių ir skirta jų poreikiams tenkinti, ją veikia daugybė makro-, mezo- ir mikroaplinkos veiksnių. Kadangi gyvenamoji aplinka yra kompleksiška, jos atnaujinimo sprendimai turi būti priimami vengiant pernelyg siauro požiūrio, nagrinejjant tik pavieniu pastatų atnaujinimo projektus. Atnaujinimo sprendimai turètų būti priimami ir projektai igyvendinami taikant holistini požiūrị. Šiuo požiūriu atnaujinimo sprendimai yra sudètingi, juos priimant būtina atsižvelgti i daugeli sąlygų ir reikalavimu. Šiame straipsnyje gyvenamosios aplinkos atnaujinimas nagrinèjamas kaip visuma, pateikiamas autorių sukurtas integruotas gyvenamosios aplinkos atnaujinimo analizès modelis, atliekama Bulgarijos kultūros paveldo atnaujinimo projektų daugiakriterinè analizè taikant gerai žinomus daugiakriterinio vertinimo metodus SAW, TOPSIS ir COPRAS bei naujai sukurtą metodą ARAS. Atlikus tyrimą išrenkamas geriausias atnaujinimo projektas, kuriam gali būti suteiktas finansavimas.

Reikšminiai žodžiai: gyvenamosios aplinkos atnaujinimas, modelis, hierarchinè kriterijų sistema, daugiakriterinis vertinimas, geriausia alternatyva.

Laura TUPENAITE. PhD student at the Department of Construction Technology and Management, Vilnius Gediminas Technical University, Lithuania. Assistant in Construction Economics and Real Estate Management Department (teaching Construction Economics). Research interests: construction economics, renovation, decision-making methods, intelligent technologies in construction.

Edmundas Kazimieras ZAVADSKAS is a principal vice-rector of Vilnius Gediminas Technical University and head of the Dept of Construction Technology and Management at Vilnius Gediminas Technical University, Vilnius, Lithuania. He has a PhD in building structures (1973) and Dr Sc (1987) in building technology and management. He is a member of Lithuanian and several foreign Academies of Sciences and doctor honoris causa at Poznan, Saint-Petersburg, and Kiev Universities. He is also a member of international organisations and was a member of steering and programme committees at many international conferences. E. K. Zavadskas is a member of editorial boards of several research journals as well as the author and co-author of more than 300 papers and a number of monographs in Lithuanian, English, German and Russian. Research interests: building technology and management, decision-making theory, automated design and decision support systems.

Arturas KAKLAUSKAS. Doctor Habil, Professor, Chair in Construction Economics and Real Estate Management Department and Vice-director of the Institute of Internet and Intelligent Technologies at the Vilnius Gediminas Technical University. Expert member of Lithuanian Academy of Sciences. He participated in 9 Framework 5 and 6 projects and author of 221 research publications and 7 monographs.

Zenonas TURSKIS. PhD, a senior research fellow in Construction Technology and Management Laboratory of Vilnius Gediminas Technical University, Lithuania. His research interests include building technology and management, decisionmaking theory, computer-aided design and expert systems. Author of 20 research papers.

Mark SENIUT. Researcher of the Institute of Internet and Intelligent Technologies, Vilnius Gediminas Technical University. Bachelor degree in informatics, Vilnius University (2004). Master degree in informatics (2006). Research interests: IT, biometric systems, intelligent decisions support systems, project management. 